\title{
Pathogenic CD8T cells in multiple sclerosis and its experimental models
}

\section{Eric S. Huseby*, Priya G. Huseby, Shivanee Shah, Rebecca Smith and Brian D. Stadinski}

Department of Pathology, University of Massachusetts Medical School, Worcester, MA, USA

Edited by:

Masaaki Murakami, Osaka University, Japan

\section{Reviewed by:}

Marco Prinz, Universitätsklinikum

Freiburg, Germany

Hideki Ogura, Osaka University, Japan

\section{*Correspondence:}

Eric S. Huseby, Department of

Pathology, University of

Massachusetts Medical School,

Worcester, MA 01655, USA.

e-mail: eric.huseby@umassmed.edu
A growing body of evidence suggests that autoreactive CD8 T cells contribute to the disease process in multiple sclerosis (MS). Lymphocytes in MS plaques are biased toward the CD8 lineage, and MS patients harbor CD8T cells specific for multiple central nervous system (CNS) antigens. Currently, there are relatively few experimental model systems available to study these pathogenic CD8T cells in vivo. However, the few studies that have been done characterizing the mechanisms used by CD8T cells to induce CNS autoimmunity indicate that several of the paradigms of how CD4 T cells mediate CNS autoimmunity do not hold true for CD8T cells or for patients with MS. Thus, myelin-specific CD4T cells are likely to be one of several important mechanisms that drive CNS disease in MS patients. The focus of this review is to highlight the current models of pathogenic CNS-reactive CD8 T cells and the molecular mechanisms these lymphocytes use when causing CNS inflammation and damage. Understanding how CNS-reactive CD8T cells escape tolerance induction and induce CNS autoimmunity is critical to our ability to propose and test new therapies for MS.

Keywords: multiple sclerosis, experimental autoimmune encephalomyelitis, $\mathrm{T}$ cells, tolerance, autoimmunity, central nervous system, MHC, TCR

\section{MULTIPLE SCLEROSIS}

Multiple sclerosis (MS) is the most common neurological disease of young adults with over one million individuals worldwide afflicted by the disease (Noseworthy et al., 2000; Hafler et al., 2005; McFarland and Martin, 2007; Steinman, 2009). MS is an inflammatory disease of the central nervous system (CNS) that causes the demyelination of nerve cells and destroys oligodendrocytes, neurons, and axons (Lucchinetti et al., 2000; Frohman et al., 2006; Dutta and Trapp, 2007). Traditionally it has been thought that MS is an inflammatory disease primarily localized to the white matter of the brain and spinal cord. However, more recent studies have identified gray matter lesions in MS patients that appear at the earliest stages, accumulate over time, and exceed white matter lesions in progressive MS patients (Peterson et al., 2001; Bo et al., 2003; Calabrese et al., 2007; Lassmann et al., 2007; Fisher et al., 2008; Ontaneda et al., 2011). Within active MS lesions, the inflammatory immune cells are predominantly $\mathrm{T}$ cells and activated macrophages and microglia, and often form focal demyelinating plaques (Frohman et al., 2006; Lassmann et al., 2007). The targeting of the CNS by immune cells and the ensuing death of neuronal tissue causes a wide spectrum of disease pathologies in MS patients (Noseworthy et al., 2000; Keegan and Noseworthy, 2002; Hafler et al., 2005; Frohman et al., 2006). The disease course can be progressive with steadily increasing neurological deficits, or manifest as a relapsing-remitting disease, with discrete attacks of disease symptoms followed by periods of clinical stability (Steinman, 2009). The clinical signs of MS are highly variable. MS patients often have symptoms of upper motor neuron disease that include hyperreflexia, ataxia, spasticity, and visual defects. In some cases there is evidence of lower motor neuron disease such as sensory defects and partial or complete paralysis (Keegan and Noseworthy, 2002).

It is hypothesized that MS is a T cell mediated autoimmune disease. This hypothesis is primarily based on the genetic susceptibility of individuals for the disease, the presence of immune cells within active MS plaques and animal models of CNS autoimmunity mediated by T cells (McFarland and Martin, 2007; Steinman, 2009). The genetic susceptibility for MS is polygenic; however, the most prominent predisposing genetic element is genes within the major histocompatibility complex (MHC) locus (Fogdell-Hahn et al., 2000; Sospedra and Martin, 2005; Hafler et al., 2007; Olsson and Hillert, 2008; Sawcer et al., 2011). The MHC locus is a large gene cluster consisting of over 200 expressed genes. Due to extensive linkage disequilibrium it has been difficult to parse out the precise predisposing genes. In MS, it is now clear that the HLA-DR15 and HLA-DQ6 alleles of MHC class II have strong disease susceptibility association with MS (Hafler et al., 2007; Olsson and Hillert, 2008; Sawcer et al., 2011). These particular MHC alleles may be displaying particular sets of peptide antigens to autoreactive T cells (Wucherpfennig, 2001). In addition to MHC genes, polymorphisms in multiple immunologically relevant genes, including IL-7R and IL-2R, have been associated with MS susceptibility (Hafler et al., 2007; Sawcer et al., 2011). Therefore, one hypothesis has been that predisposing MHC class II alleles present particular disease relevant epitopes to dysregulated, pathogenic T cells. However, other MHC class II alleles can confer some protection from disease even when the susceptible MHC class II allele is expressed (Olsson and Hillert, 2008; Ramagopalan et al., 2009). This suggests that the role of MHC in autoimmunity is 
likely to be multi-layered, involving functions from multiple gene products.

CD4 T cells specific for many CNS proteins, including myelin associated glycoprotein (MAG), myelin basic protein (MBP), myelin oligodendrocyte glycoprotein (MOG), and proteolipid protein (PLP), can be isolated from MS patients and healthy individuals (Sospedra and Martin, 2005). These data, combined with evidence that MHC class II alleles confer the strongest genetic susceptibility, has suggested that in patients with MS, CNS proteinspecific CD4 T cells become activated, cross the blood/brain barrier, and induce CNS autoimmunity (Sospedra and Martin, 2005; Steinman, 2009). Further support for this hypothesis comes from the many animal models of CD4 $\mathrm{T}$ cell mediated experimental autoimmune encephalomyelitis (EAE), that manifest clinical and pathological symptoms with many similarities to MS (Kuchroo et al., 2002; Ercolini and Miller, 2006; Goverman, 2009).

\section{EXPERIMENTAL AUTOIMMUNE ENCEPHALOMYELITIS}

Animal models of CNS autoimmunity are primarily focused on the role of Th1 and Th17 phenotype CD4 T cell mediated pathology (Bettelli et al., 2007; Goverman, 2009). The majority of CNS proteins identified that can be targets of EAE-inducing CD4 T cells are components of compact myelin or proteins associated with myelin synthesis (Sospedra and Martin, 2005). The classical animal model of MS, CD4 T cell mediated EAE (CD4-EAE), is induced by immunizing animals with myelin proteins or peptides emulsified in complete Freund's adjuvant. This protocol predominantly induces Th1 and Th17 phenotype CD4 T cell responses, and is a poor elicitor of CD8 responses (Zamvil and Steinman, 1990; Cua et al., 2003). In addition, CD4-EAE is induced by transferring CNS-specific Th1 or Th17 CD4 T cells into naïve recipient animals (Zamvil and Steinman, 1990; Langrish et al., 2005; Lees et al., 2008; O'Connor et al., 2008; Jager et al., 2009). Similar to patients with MS, the disease course of CD4-EAE can be acute, relapsing/remitting, or chronic progressive. However, the disease pathologies associated with CD4-EAE are usually less diverse than the disease symptoms in MS patients (Steinman and Zamvil, 2005; Friese et al., 2006; Gold et al., 2006).

The major mouse models of EAE-MOG induced EAE in C57BL/6 mice, MBP induced EAE in B10.PL mice, and PLP mediated disease in SJL mice - present symptoms of ascending flaccid paralysis (Zamvil and Steinman, 1990; Vanderlugt and Miller, 2002). The disease begins with a loss of tail tone and can progress through an ascending paralysis affecting the rear legs, followed by the fore legs until the animals become morbid. These pathologies are reminiscent of MS patients with lower motor neuron disease (Keegan and Noseworthy, 2002). There are some models of CD4EAE that present "atypical" axial-rotatory disease, characterized by mice that roll continuously or have severe deficiency in balance without paralysis (Greer et al., 1996; Sobel, 2000; AbromsonLeeman et al., 2007; Lees et al., 2008; Stromnes et al., 2008). Several studies have shown that the ratio of Th1 versus Th17, or the ability of CNS cells to respond to IFN $\gamma$ signaling, contributes to the location of affected CNS area and/or the presentation of classical or atypical disease symptoms (Lees et al., 2008; Stromnes et al., 2008; Jager et al., 2009). The genetic background of mice that get CD4 $\mathrm{T}$ cell mediated atypical EAE include $\mathrm{C} 57 \mathrm{BL} / 6, \mathrm{Balb} / \mathrm{c}$, and $\mathrm{C} 3 \mathrm{H}$ mice, genetic backgrounds that also develop classical ascending paralytic disease when immunized with different CNS antigens (Sobel, 2000). Thus, there are indications that the immunizing antigen, T cell trafficking and/or the phenotype of the CD4 T cells, and not necessarily the genetic background, may be determining factors in the induction of non-classical disease symptoms of EAE. Overall, although there are heterogenic disease pathologies induced by CD4 T cells, CD4-EAE still likely mimics some, but not all, aspects of CNS inflammation in MS.

Autoreactive CD4 T cells alone are unlikely to fully account for all of the effector mechanisms that drive the disease process in MS. Disease inducing, myelin-specific CD4 T cells within the CNS release the signature Th1 and Th17 cytokines. The release of cytokines and chemokines causes an increase in MHC expression within the CNS, leads to the activation of microglia, and induces the recruitment of monocytes and non-specific $\mathrm{T}$ cells to the area of inflammation (Prineas, 1979; Raine et al., 1984; Carson et al., 1999; Brabb et al., 2000; Krakowski and Owens, 2000; Juedes and Ruddle, 2001; Becher et al., 2006; Mildner et al., 2008). Several of these cytokines, including IFN $\gamma, \mathrm{TNF} \alpha$, IL-6, IL-12, and IL-23, have been directly implicated in disease pathogenesis (Krakowski and Owens, 1996; Okuda et al., 1998; Sean Riminton et al., 1998; Steinman, 2001; Cua et al., 2003; Deshpande et al., 2006). Using the CD4-EAE disease model as a screen, several therapies that ameliorate CD4-EAE have been developed for clinical trials to reduce symptoms in MS patients. While some of the treatments validated in the CD4-EAE model have reduced disease symptoms in MS patients, other therapies have not affected clinical symptoms, or have been detrimental to patients (Steinman and Zamvil, 2005; Friese et al., 2006; Gold et al., 2006). For example, the removal of CD4 T cells or TNF $\alpha$ from MS patients had little effect on disease symptoms, while both abolish disease in CD4-EAE models (Waldor et al., 1985; Llewellyn-Smith et al., 1997; van Oosten et al., 1997; Sean Riminton et al., 1998; Lenercept, 1999). Thus, CD4EAE probably mimics only a subset of the events that occur during MS. The discovery of other key events in the pathogenesis of MS disease will be facilitated by animal models that mimic events not already evoked by CD4 T cells.

\section{CD8 T CELLS IN MULTIPLE SCLEROSIS}

The lymphocytes in MS plaques are biased toward the CD8 lineage. This bias occurs regardless of the stage of activity or disease, and can be as prominent as 10:1, CD8 versus CD4 T cells (Booss et al., 1983; Traugott et al., 1983b; Hauser et al., 1986; Babbe et al., 2000; Lassmann et al., 2007). At the margin of chronic and active lesions, CD8 T cells have been identified interacting with antigen presenting cells (APC; Serafini et al., 2006). Through normally poorly expressed, MHC class I proteins are highly expressed within the MS lesion on astrocytes, oligodendrocytes, and neurons, implying that CD8 T cells could be directly engaging these cell types as well (Traugott et al., 1983a; Wong et al., 1984a; Neumann et al., 1995, 1997). CD8 T cells with an activated/memory phenotype have been observed to be enriched within the CNS tissue and cerebrospinal fluid (CSF) of MS patients (Jacobsen et al., 2002; Junker et al., 2007), and histological analysis of some cases of acute MS have shown granzyme B-expressing CD8 T cells in close proximity or attached to oligodendrocytes or demyelinated axons 
(Neumann et al., 2002; Serafini et al., 2006; Lassmann et al., 2007). Interestingly, Fugger and colleagues have found that a large percentage of CD8 T cells in acute and chronic MS lesions express IL-17 (Tzartos et al., 2008), a highly pro-inflammatory cytokine associated with pathogenic Th17 CD4 T cells and Tc17 CD8 T cells (Cua et al., 2003; Bettelli et al., 2007). This activated/memory phenotypic skewing of CD8 T cells within the CSF occurs even in early diagnosed MS patients. Furthermore, Brück and colleagues demonstrated that the number of CD8 T cells and macrophages within the lesions correlates with the extent of acute axonal damage, as defined by the accumulation of amyloid precursor protein (APP; Bitsch et al., 2000). In addition, genetic association studies have identified some MHC class I alleles, including HLA-A3, as a genetic susceptibility allele (Friese and Fugger, 2005; Sawcer et al., 2011). In contrast, the MHC class I allele, HLA-A*0201, has been shown to reduce the risk of MS in individuals that express the MHC class II proteins, HLA-DRB1*1501, and DQB1*06 (FogdellHahn et al., 2000; Brynedal et al., 2007). These observations support the idea that CD8 T cells are involved in pathogenesis of MS, as active contributors to the development of MS lesions, and/or as protective regulatory $\mathrm{T}$ cell populations that limit disease.

Several groups have isolated $\mathrm{T}$ cells from the blood, CSF, and MS lesions (via microdissection), and analyzed these lymphocytes by complementarity determining region 3 (CDR3) spectratyping to determine the diversity of $\mathrm{T}$ cell clones. Initial studies by Babbe et al. (2000) demonstrated that the majority of CD8 T cells within an MS plaque were progeny of a few initial clones. One particular clone accounted for $35 \%$ of the CD8 T cells within an MS plaque. Later studies analyzing larger numbers of MS patients demonstrated that CD8 $\mathrm{T}$ cells isolated from CSF fluid also contained clonal expansions, some of which persisted for 5 years (Jacobsen et al., 2002; Skulina et al., 2004). To identify the antigen specificity of these CD 8 T cells, paired TCR $\alpha$, and TCR $\beta$ chains have been cloned and re-expressed in $\mathrm{T}$ cell lines (Seitz et al., 2006). However, the antigen specificity of these CD8 $\mathrm{T}$ cells has yet to be determined. Although the specificity of the CD8 T cells in MS plaques is unknown, their clonal nature suggests that they are responding against selected antigens.

Central nervous system-reactive CD8 T cells may be pathogenic in MS patients. Pioneering studies by Biddison and colleagues and Hafler and colleagues identified and analyzed CD8 T cells specific for several CNS proteins, including MAG, MBP, and PLP, from MS patients (Tsuchida et al., 1994; Dressel et al., 1997). These studies clearly demonstrated that MS patients carry a population of CD8 T cells specific for myelin proteins. These MAG-, MBP-, and PLP-specific CD8 T cells are capable of killing neuronal cells in vitro and release TNF $\alpha$ and IFN $\gamma$, suggesting that they may contribute to CNS disease, although the precise role of these cells in the pathogenesis of MS has not been fully elucidated (Tsuchida et al., 1994; Jurewicz et al., 1998; Medana et al., 2001). More recent analysis of peripheral blood suggests that MS patients carry CD8 $\mathrm{T}$ cells able to express IFN $\gamma$ and TNF $\alpha$ in response to a multitude of CNS protein epitopes. Several studies have demonstrated that these CNS-reactive CD8 T cells were found in greater frequency and bore an activated/memory phenotype in MS patients, suggesting they had been activated within the patient by CNS antigens (Crawford et al., 2004; Zang et al., 2004; Niland et al., 2005).
In contrast, these same $\mathrm{T}$ cells isolated from control subjects displayed a naïve $\mathrm{T}$ cell phenotype. Differences in the frequency of CNS antigen-specific CD8 T cells between MS patients and control subjects have not always been observed, as myelin-reactive CD8 T cells have been identified in healthy subjects as well (Berthelot et al., 2008). This group of studies clearly indicates that individuals carry a population of CD8 T cells specific for a variety of CNS antigens. The presence of CNS-reactive T cells exhibiting an activated/memory phenotype in MS patients and the oligoclonal nature of CD8 $\mathrm{T}$ cells within MS plaques suggest that CD8 T cells are active participants within the destructive CNS immune response.

In addition to a pathogenic role for CD8 $\mathrm{T}$ cells in MS, regulatory CD8 T cells may contribute to limiting disease severity or occurrence in MS patients. Early experiments demonstrated that the suppressor function of CD8 T regulatory cells in MS patients may be defective as compared to healthy individuals (Antel et al., 1986). Consistent with these findings, a specific CD8 T cell clone has been shown to regulate MBP-specific CD4 T cells (Chou et al., 1992). CD8 T cells that can lyse myelin-specific CD4 T cells have been detected in MS patients, and vaccination of MS patients with irradiated myelin-specific CD4 T cells elicited CD8 T cells that could specifically kill these CD4 T cells (Zhang et al., 1993; Correale et al., 2000). More recently, longitudinal magnetic resonance imaging (MRI) analysis has shown a negative correlation between the percentage of Tc2 cytokine-producing CD8 T cells in the periphery of MS patients and the development of lesions (Killestein et al., 2003). Furthermore, the beneficial effects of treating MS patients with glatiramer acetate may in part be due to activating regulatory CD8 T cells (Tennakoon et al., 2006). In addition to these, and many other studies of human CD8 T regulatory cells, mouse models have also shown potent disease modifying effects of CD8 T regulatory cells through the secretion of IL-10 and other soluble mediators, the regulation of APC function, as well as by eliminating activated $\mathrm{CD} 4 \mathrm{~T}$ cells by CD8 $\mathrm{T}$ cells via recognition of the non-classical Qa-1 MHC molecule (Jiang and Chess, 2006; Goverman, 2009).

\section{ANIMAL MODELS OF CD8 T CELL MEDIATED CNS AUTOIMMUNITY}

Several years ago we and others started developing CD8 T cell models of CNS autoimmunity. At the time, MS was generally believed to be primarily a $\mathrm{CD} 4 \mathrm{~T}$ cell mediated autoimmune disease. However, because MS plaques contain a large excess of CD8 T cells relative to $\mathrm{CD} 4 \mathrm{~T}$ cells, we were concerned that a major lymphocyte population within the inflamed site was being under studied. Because of the cytotoxic and pro-inflammatory nature of CD8 T cells, we hypothesized that myelin-specific CD8 T cells contribute to CNS autoimmunity. Our studies focused on whether MBP-specific CD8 $\mathrm{T}$ cells could induce CNS autoimmunity. Because MBP is a self protein, we were concerned that CD8 T cells specific for MBP might be subject to immune tolerance mechanisms. To avoid tolerance issues, we initially isolated MBP-reactive CD8 T cells from $\mathrm{C} 3 \mathrm{H}$ MBP-deficient shiverer $\left(\mathrm{C} 3 \mathrm{H} \mathrm{MBP}{ }^{-l-}\right.$ ) mice (Huseby et al., 1999). These studies demonstrated that MBP-specific CD8 $\mathrm{T}$ cells, similar to several CD4 T cell epitopes of MBP and PLP, are subject to immune tolerance (Goverman, 2011). However, some 
MBP-specific CD8 T cells are present in the peripheral repertoire of wild-type $\mathrm{C} 3 \mathrm{H}$ mice. Furthermore, the activation of MBPspecific CD8 T cells in animals induces severe, demyelinating CNS autoimmunity (Huseby et al., 2001a).

The pathology of MBP-specific CD8 T cell mediated disease had many similarities to some human MS patients (Lucchinetti et al., 2000), including the presence of lesions throughout the brain (Huseby et al., 2001a). Histological analysis of diseased brains indicated the lesions were vascular in nature, involving capillaries and venules, and consisted of perivascular cuffing. Vacuolation of the surrounding nervous tissue was common and consisted of demyelination and cytoplasmic swelling. In contrast to many typical CD4-EAE models, this MBP-specific CD8 T cell mediated disease model had a predominance of lesions in the brain instead of the spinal cord, displayed a general lack of inflammation (except that which was directly associated with vascular walls), and showed severe demyelination and perivascular cell death, suggesting a cytotoxic or ischemic injury. Antibody blocking experiments demonstrated a role for IFN $\gamma$ in contributing to disease severity (Huseby et al., 2001a). Using TCR Tg mice that generate MBP-specific CD8 T cells, Goverman and colleagues have gone on to show how endogenous MBP influences this T cell repertoire (Perchellet et al., 2004, 2008), and have demonstrated that viruses can induce CD8 T cell-mediated autoimmunity by breaking peripheral tolerance mechanisms (Ji et al., 2010).

CD8 $\mathrm{T}$ cell lines reactive to the MOG derived peptide, $\mathrm{MOG}_{35-55}$, can induce chronic CNS autoimmunity in C57BL/6 mice (Sun et al., 2001; Ford and Evavold, 2005). Unlike the disease symptoms induced by MBP-specific CD8 T cells, these MOGreactive $\mathrm{CD} 8 \mathrm{~T}$ cell lines induced ascending flaccid paralysis, and caused lesions in both the spinal cord and brain. The reason for the differences in disease symptoms between the MBP and MOG models of CD8-EAE is unknown. The differences could be due to the CD8 $\mathrm{T}$ cells targeting different proteins or due to differences between the $\mathrm{C} 3 \mathrm{H}$ and $\mathrm{C} 57 \mathrm{BL} / 6$ genetic backgrounds.

Humanized mouse models have been used to study CD8 T cell responses targeting myelin epitopes presented by human HLA-A molecules. CD8 T cells targeting $\mathrm{MOG}_{181-189}$, presented by the MHC class I allele, HLA-A*0201, were observed to potentiate an autoreactive CD4 $\mathrm{T}$ cell response by accelerating and worsening the encephalitogenic process (Mars et al., 2007). Friese et al. (2008) have more recently generated a humanized mouse model of MS in which an MHC class I-restricted TCR specific for PLP $\mathrm{P}_{45-53}$ bound to HLA-A*0301, isolated from an MS patient, is expressed in mice which also express the MHC Class I molecule HLA-A*0301. These mice, constructed on a C57BL/6 genetic background, develop a low grade spontaneous MS-like disease which becomes more severe upon immunization with PLP peptides. Following immunization with PLP peptides, there are two phases of disease, an early infiltration that is dominated by CD8 T cells and late disease that requires MHC class II expression. Coincident with the late disease is the expansion within the CNS of CD4 T cells reactive to $\mathrm{MOG}_{35-55}$. These experiments nicely demonstrate that $\mathrm{T}$ cells expressing a human MHC class I-restricted TCR specific for a CNS protein can be pathogenic and can induce epitope spreading to the CD4 T cell compartment. When the human TCR Tg mice were crossed onto mice expressing HLA-A 0301 and the protective MHC class I allele, HLA-A*0201, thymocytes expressing this PLP-specific TCR were subject to elimination by negative selection. T cells expressing the $\mathrm{PLP}_{45-53}$-specific TCR did not recognize the $\mathrm{PLP}_{45-53}$ epitope bound to HLA-A*0201, suggesting the elimination of these pathogenic $\mathrm{T}$ cells was not induced by recognizing endogenous PLP (Friese et al., 2008). The induction of negative selection in mice expressing HLA-A*0201 support the hypothesis that one of the protective effects of specific MHC class I alleles is the elimination of pathogenic T cells during development.

Complementing the active induction models are a set of mice which spontaneously succumb to CD8 T cell-dependent CNS autoimmunity. Fournier and colleagues observed that transgenic C57BL/6 mice, in which the co-stimulatory molecule CD86 is constitutively expressed on peripheral $\mathrm{T}$ cells and resident CNS microglia, succumb to a CD8 T cell-dependent CNS demyelinating disease (Brisebois et al., 2006). CNS infiltration by CD8 T cells results in mice which display a deterioration of hind-limb control and coordination, weak tail movement, and weight loss. The age at which these mice succumb to spontaneous disease is younger in both MHC class II-deficient mice as well as CD4-deficient mice, suggesting the pathogenic CD8 $\mathrm{T}$ cells are being regulated by a CD4 $\mathrm{T}$ cell populations. The specificity of these pathogenic CD8 $\mathrm{T}$ cells has yet to be determined. The non-paralytic disease symptoms and pathologies in CD86 transgenic mice are similar to the $\mathrm{MBP}$-specific CD8 $\mathrm{T}$ disease model in $\mathrm{C} 3 \mathrm{H}$ mice, while differing from the paralytic disease mediated by $\mathrm{MOG}_{35-55}$ specific CD8 T cells. Two additional models have recently been observed in which pathogenic CD8 T cells induce both clinical signs of CNS disease as well as demyelination. Mice over-expressing PLP within oligodendrocytes of the CNS developed progressive clinical signs of neurological damage including ataxia, tremors, and seizures after 12-18 months of age that was dependent up CD8 T cells (Ip et al., 2006). CD8 T cells and macrophages accumulated within the brains of these mice, with a limited B cell and CD4 T cell component. Affected areas of the CNS included the optic nerve, cerebral white matter, and spinal cord. Mice in which the oligodendrocytes are deficient in peroxisome show a similar axonal loss and neuroinflammation as the PLP over-expressing mice (Kassmann et al., 2007). The antigen specificity of the CNS infiltrating CD8 T cells remains unknown in both models. These spontaneous models, along with the active induction models, further suggest that CD8 $\mathrm{T}$ cells can induce a range of different disease manifestations, and clearly demonstrate that CNS-specific CD8 T cells are present in the peripheral $\mathrm{T}$ cell repertoire and when activated, can induce CNS autoimmunity.

\section{CELLULAR TARGETS OF PATHOGENIC CD8 T CELLS}

The cellular target of pathogenic myelin-specific CD8 T cells in vivo is unknown. Normally, there is very little MHC class I expression in the CNS. Neurons and oligodendrocytes express only low levels of MHC class I, constitutively. Astrocytes, microglia, blood vessel endothelial cells, and bone marrow derived-APC (BM-APC) resident within the CNS do express MHC class I constitutively, though none of these cells synthesize myelin antigens (Traugott et al., 1983a; Wong et al., 1984a; Massa et al., 1993; Neumann et al., 1995, 1997; Hoftberger et al., 2004; Frohman et al., 2006). However, BM-APC, and to a lesser extent, blood vessel 
endothelial cells, can cross-present exogenously synthesized proteins on MHC class I proteins (Limmer et al., 2000; Rock and Shen, 2005; Galea et al., 2007). Thus, the initial recognition of myelin peptides presented on MHC class I proteins is likely by BM-APC or blood vessel endothelial cells. Whether CD8 T cells can directly lyse oligodendrocytes in vivo is unknown. MHC expression by oligodendrocytes does increase after inflammation or in response to IFN $\gamma$, therefore it may be possible for CD8 T cells to directly target oligodendrocytes once inflammation begins (Wong et al., 1984a,b; Tsuchida et al., 1994; Neumann et al., 1997; Hoftberger et al., 2004). Thus, it is not surprising that when we and others neutralized IFN $\gamma$, the severity of CD8-EAE disease is drastically reduced (Huseby et al., 2001a; Brisebois et al., 2006).

To begin to identify which CNS cell types could be targets of CD8 $\mathrm{T}$ cells, several groups have created transgenic mice which express neo-self antigens in specific cell populations. The first of these models, created by the Oldstone group, expressed the lymphocytic choriomeningitis virus (LCMV) glycoprotein under the MBP promoter (Evans et al., 1996). These mice expressed very low levels of the LCMV protein exclusively in the brain, likely in oligodendrocytes. Following two subsequent viral infections, focal areas of myelin degradation were observed, and expression of both MHC class I and class II molecules was found on oligodendrocytes. These data suggested that CD8 and/or CD4 T cells may interact directly with oligodendrocytes and play a role in oligodendrocyte injury. More recently, two sets of mice expressing either ovalbumin (OVA) or the influenza virus hemagglutinin (HA) proteins selectively within oligodendrocytes, have been constructed and analyzed.

When mice expressing OVA selectively in oligodendrocytes (ODC-OVA) were genetically crossed with OT-1 mice, transgenic mice expressing a TCR specific for $\mathrm{OVA}_{257-264}$ presented by $\mathrm{H} 2-\mathrm{K}^{\mathrm{b}}$, the double transgenic mice succumbed to an extremely aggressive, lethal fulminant demyelinating CNS autoimmunity (Na et al., 2008). Lesions within the cerebellum, brainstem, optic nerve, and spinal cord were observed. In vitro, OVA-transgenic oligodendrocytes were capable of activating naïve OT-I cells. The potency of OVA-expressing oligodendrocytes to activate OT-I CD8 T cells in vitro was further amplified by the addition of exogenous IFN $\gamma$ to the cultures. The secretion of IFN $\gamma$ from OT-1 T cells was also found to be required for the loss of oligodendrocytes, as well as axon damage within the CNS. In contrast to this model, Balb/c mice expressing the HA protein in oligodendrocytes (MOG-HA) did not develop spontaneous autoimmunity when crossed with transgenic mice expressing an HA-specific TCR, Cl4, that recognizes $\mathrm{HA}_{512-520}$ presented by $\mathrm{H} 2-\mathrm{K}^{\mathrm{d}}$ (Saxena et al., 2008). In these mice, the HA-specific CD8 $\mathrm{T}$ cells maintained ignorance to the neo-self protein. However, transfer of in vitro activated HA-specific CD8 T cells induced weight loss, demyelination, and reduced mobility, but not paralysis. The inflammatory lesions were primarily within the spinal cord and optic nerve. HA-specific CD8 T cells within the CNS were found in close apposition with oligodendrocytes and some had polarized Granzyme B containing granules toward the oligodendrocytes (Saxena et al., 2008). The loss of oligodendrocytes prior to demyelination suggests these CD8 T cells are directly killing these cells. Interestingly, when these same HA-specific CD8 T cells are transferred into mice expressing the HA protein selectively in astrocytes, the mice developed a monophasic brain inflammation with an absence of any clinical signs of disease (Cabarrocas et al., 2003). Combined, these data suggest that CD8 $\mathrm{T}$ cells, which have a strong reactivity for an epitope that is processed and presented well on MHC class I molecules, can directly target oligodendrocytes within the CNS. The differences in disease course and severity among the transgenic neo-self models of CD8 T cell mediated CNS autoimmunity further suggests that a multitude of factors, including target antigen expression level, CNS cell type expression, TCR-pMHC affinity, and genetics, likely contribute to whether a CD8 T cell response is pathogenic.

\section{WHY ARE PATHOGENIC CNS-REACTIVE CD8 T CELLS PRESENT WITHIN THE MATURE T CELL REPERTOIRE?}

The $\mathrm{T}$ cell mediated autoimmune nature of MS and EAE indicates that $\mathrm{T}$ cell tolerance of CNS proteins is incomplete. During $\mathrm{T}$ cell development, TCR undergo somatic recombination of their peptide and MHC binding CDR3 loops, as well as TCR $\alpha / \beta$ chain pairing (Davis and Bjorkman, 1988). The immense TCR diversity generated during $\mathrm{T}$ cell development allows the adaptive immune response to be able to generate specific $\mathrm{T}$ cell responses to unknown pathogens. This process, however, also creates self-reactive $\mathrm{T}$ cells. Many of these self-reactive $T$ cells are purged during negative selection, due to the expression of the self protein within the thymus by dendritic cells or medullary thymic epithelial cells (Kappler et al., 1987; Kisielow et al., 1988; Mathis and Benoist, 2004; Kyewski and Klein, 2006). However, some self-reactive T cells that escape negative selection are then subject to peripheral tolerance mechanisms (Zheng and Rudensky, 2007). Autoimmune diseases arise when failures of thymic and peripheral tolerance mechanisms allow selfreactive $T$ cells to be activated and attack healthy tissues. It has been clearly established that endogenous MBP induces some tolerance to the CD4 and CD8 T cell repertoire (Goverman, 2011). PLP also appears to induce some tolerance to the $\mathrm{CD} 4 \mathrm{~T}$ cell repertoire specific for it (Kuchroo et al., 2002). Because MBP and PLP are expressed at extremely high levels within the CNS and some isoforms of these proteins are expressed within the thymus (albeit at extremely low levels by medullary thymic epithelial cells), it is not surprising some $\mathrm{T}$ cell tolerance occurs (Kyewski and Klein, 2006). Negative selection can also occur to T cells specific for CNS proteins not expressed in the thymus. Our studies of CD4 T cells specific for $\mathrm{MBP}_{121-140}$, an epitope that is not expressed in the thymus, indicate that BM-APC can acquire MBP from exogenous sources and cause the elimination of developing $\mathrm{T}$ cells (Huseby et al., 2001b). The extremely low level of MOG (around 1,0005,000 times less abundant than MBP and PLP within the CNS) does not appear to induce significant tolerance to the CD4 T cell repertoire (Delarasse et al., 2003). It has not been determined whether other myelin proteins induce CD4 T cell tolerance, nor is it known whether CNS proteins other than MBP induce tolerance to the $\mathrm{CD} 8 \mathrm{~T}$ cell repertoire.

There are three main hypotheses for how pathogenic myelinreactive $T$ cells escape tolerance induction in the thymus, primarily derived from studies of CD4 T cell responses: (1) T cells specific for exons of myelin proteins neither expressed nor presented within the thymus fail to be deleted because the antigen is not presented to 
developing thymocytes (Kuchroo et al., 2002; Kyewski and Klein, 2006). (2) For myelin proteins that are presented well in the thymus, central tolerance eliminates thymocytes expressing TCR that have a strong reactivity for these myelin antigens while allowing thymocytes expressing TCR which have a weak reactivity to develop (Goverman, 2011). Thymocytes that escape this form of central tolerance may express TCR with a low affinity for myelin epitopes bound to self-MHC proteins, or express TCR that bind myelin epitopes bound to self-MHC with unconventional binding modes (Wucherpfennig et al., 2009). (3) Autoreactive T cells specific for myelin proteins that are expressed in the thymus but are poorly presented (e.g., peptide sequences that bind MHC proteins poorly) may not be deleted because the amount of $\mathrm{MHC}+$ peptide complex in the thymus is very low (Goverman et al., 1993; Liu et al., 1995). Myelin-specific T cells expressing low affinity TCR, TCR that bind pMHC with unconventional bind modes, or TCR that target epitopes that are poorly presented may be pathogenic because the expression level of the myelin protein is much higher in the CNS than thymus, and thus APC within the CNS can present enough $\mathrm{MHC}+$ peptide complexes to activate these lymphocytes.

Do these models of $\mathrm{T}$ cell tolerance to myelin antigens hold true for CD8 T cells as well? Though little is currently known about how CNS-reactive CD8 T cells escape tolerance induction,

\section{REFERENCES}

Abromson-Leeman, S., Ladell, D. S., Bronson, R. T., and Dorf, M. E. (2007). Heterogeneity of EAE mediated by multiple distinct T-effector subsets. J. Neuroimmunol. 192, 3-12.

Antel, J. P., Bania, M. B., Reder, A., and Cashman, N. (1986). Activated suppressor cell dysfunction in progressive multiple sclerosis. J. Immunol. 137, 137-141.

Babbe, H., Roers, A., Waisman, A., Lassmann, H., Goebels, N., Hohlfeld, R., Friese, M., Schroder, R., Deckert, M., Schmidt, S., Ravid, R., and Rajewsky, K. (2000). Clonal expansions of CD8(+) $\mathrm{T}$ cells dominate the $\mathrm{T}$ cell infiltrate in active multiple sclerosis lesions as shown by micromanipulation and single cell polymerase chain reaction. J. Exp. Med. 192, 393-404.

Becher, B., Bechmann, I., and Greter, M. (2006). Antigen presentation in autoimmunity and CNS inflammation: how $\mathrm{T}$ lymphocytes recognize the brain. J. Mol. Med. 84, 532-543.

Berthelot, L., Laplaud, D. A., Pettre, S., Ballet, C., Michel, L., Hillion, S., Braudeau, C., Connan, F., Lefrere, F., Wiertlewski, S., Guillet, J. G., Brouard, S., Choppin, J., and Soulillou, J. P. (2008). Blood CD8+ T cell responses against myelin determinants in multiple sclerosis and healthy individuals. Eur. J. Immunol. 38, 1889-1899.

Bettelli, E., Oukka, M., and Kuchroo, V. K. (2007). T(H)-17 cells in the circle of immunity and autoimmunity. Nat. Immunol. 8, 345-350.

Bitsch, A., Schuchardt, J., Bunkowski, S., Kuhlmann, T., and Bruck, W. (2000). Acute axonal injury in multiple sclerosis. Correlation with demyelination and inflammation. Brain 123 (Pt 6), 1174-1183.

Bo, L., Vedeler, C. A., Nyland, H. I., Trapp, B. D., and Mork, S. J. (2003). Subpial demyelination in the cerebral cortex of multiple sclerosis patients. J. Neuropathol. Exp. Neurol. 62, 723-732.

Booss, J., Esiri, M. M., Tourtellotte, W. W., and Mason, D. Y. (1983). Immunohistological analysis of $\mathrm{T}$ lymphocyte subsets in the central nervous system in chronic progressive multiple sclerosis. J. Neurol. Sci. 62, 219-232.

Brabb, T., von Dassow, P., Ordonez, N., Schnabel, B., Duke, B., and Goverman, J. (2000). In situ tolerance within the central nervous system as a mechanism for preventing autoimmunity. J. Exp. Med. 192, 871-880.

Brisebois, M., Zehntner, S. P., Estrada, J., Owens, T., and Fournier, S. (2006). A pathogenic role for CD8+ $\mathrm{T}$ cells in a spontaneous model of demyelinating disease. J. Immunol. 177, 2403-2411.

Brynedal, B., Duvefelt, K., Jonasdottir, G., Roos, I. M., Akesson, E., Palmgren, J., and Hillert, J. (2007). HLA-A confers an HLA-DRB1 independent

it was very surprising that some CD8 T cells with a strong reactivity for $\mathrm{MBP}_{79-87}$ were allowed to develop and seed the mature $\mathrm{T}$ cell repertoire (Huseby et al., 2001a). This myelin epitope is expressed within the thymus and most $\mathrm{T}$ cells with a strong reactivity for this epitope are eliminated. Using a completely novel mechanism to escape tolerance induction, Perchellet et al. (2004) found that $\mathrm{MBP}_{79-87}$-specific CD8 T cells could avoid both central and peripheral deletion by removing $\mathrm{H} 2 \mathrm{~K}^{\mathrm{k}}-\mathrm{MBP}_{79-87}$ complexes from APC without proliferating. Thus, the major form of immune regulation that governs myelin-specific CD4 T cells may not fully explain the development and control of CNS-reactive CD8 T cells. To understand why CNS autoimmunity arises, it will be important to identify the pathways in which CNS-reactive CD4 and CD8 T cells are normally eliminated or regulated, and why these processes fail in patients with MS. Overall, how similar or different the contribution of CNS-reactive CD4 versus CD8 T cells to the disease pathologies of MS is just beginning to be understood.

\section{ACKNOWLEDGMENTS}

The authors would like to thank the grant support from the NIH, grant to Eric S. Huseby (RAI088495A), and a NIH training grant to Brian D. Stadinski (T32 AI 007349). Eric S. Huseby is a member of the UMass DERC (grant DK32520).

influence on the risk of multiple sclerosis. PLoS ONE 2, e664. doi:10.1371/journal.pone.0000664

Cabarrocas, J., Bauer, J., Piaggio, E., Liblau, R., and Lassmann, H. (2003). Effective and selective immune surveillance of the brain by $\mathrm{MHC}$ class I-restricted cytotoxic T lymphocytes. Eur. J. Immunol. 33, 1174-1182.

Calabrese, M., De Stefano, N., Atzori, M., Bernardi, V., Mattisi, I., Barachino, L., Morra, A., Rinaldi, L., Romualdi, C., Perini, P., Battistin, L., and Gallo, P. (2007). Detection of cortical inflammatory lesions by double inversion recovery magnetic resonance imaging in patients with multiple sclerosis. Arch. Neurol. 64, 1416-1422.

Carson, M. J., Reilly, C. R., Sutcliffe, J. G., and Lo, D. (1999). Disproportionate recruitment of CD8+ $\mathrm{T}$ cells into the central nervous system by professional antigenpresenting cells. Am. J. Pathol. 154, 481-494.

Chou, Y. K., Henderikx, P., Jones, R. E., Kotzin, B., Hashim, G. A., Offner, H., and Vandenbark, A. A. (1992). Human CD8+ T cell clone regulates autologous CD4+ myelin basic protein specific T cells. Autoimmunity 14, 111-119.

Correale, J., Lund, B., McMillan, M., Ko, D. Y., McCarthy, K., and Weiner, L. P. (2000). T cell vaccination in secondary progressive multiple sclerosis. J. Neuroimmunol. 107, 130-139.

Crawford, M. P., Yan, S. X., Ortega, S. B., Mehta, R. S., Hewitt, R. E., Price, D. A., Stastny, P., Douek, D. C., Koup, R. A., Racke, M. K., and Karandikar, N. J. (2004). High prevalence of autoreactive, neuroantigen-specific CD8+ $\mathrm{T}$ cells in multiple sclerosis revealed by novel flow cytometric assay. Blood 103, 4222-4231.

Cua, D. J., Sherlock, J., Chen, Y., Murphy, C. A., Joyce, B., Seymour, B., Lucian, L., To, W., Kwan, S., Churakova, T., Zurawski, S., Wiekowski, M., Lira, S. A., Gorman, D., Kastelein, R. A., and Sedgwick, J. D. (2003). Interleukin23 rather than interleukin-12 is the critical cytokine for autoimmune inflammation of the brain. Nature 421, 744-748.

Davis, M. M., and Bjorkman, P. J. (1988). T-cell antigen receptor genes and T-cell recognition. Nature 334, 395-402.

Delarasse, C., Daubas, P., Mars, L. T., Vizler, C., Litzenburger, T., Iglesias, A., Bauer, J., Della Gaspera, B., Schubart, A., Decker, L., Dimitri, D., Roussel, G., Dierich, A., Amor, S., Dautigny, A., Liblau, R., and Pham-Dinh, D. (2003). Myelin/oligodendrocyte glycoprotein-deficient (MOGdeficient) mice reveal lack of immune tolerance to MOG in wild-type mice. J. Clin. Invest. 112 , 544-553. 
Deshpande, P., King, I. L., and Segal, B. M. (2006). IL-12 driven upregulation of P-selectin ligand on myelinspecific $T$ cells is a critical step in an animal model of autoimmune demyelination. J. Neuroimmunol. 173, 35-44.

Dressel, A., Chin, J. L., Sette, A., Gausling, R., Hollsberg, P., and Hafler, D. A. (1997). Autoantigen recognition by human CD8 $\mathrm{T}$ cell clones: enhanced agonist response induced by altered peptide ligands. J. Immunol. 159, 4943-4951.

Dutta, R., and Trapp, B. D. (2007). Pathogenesis of axonal and neuronal damage in multiple sclerosis. Neurology 68, S22-S31; discussion S43-S54.

Ercolini, A. M., and Miller, S. D. (2006). Mechanisms of immunopathology in murine models of central nervous system demyelinating disease. J. Immunol. 176, 3293-3298.

Evans, C. F., Horwitz, M. S., Hobbs, M. V., and Oldstone, M. B. (1996). Viral infection of transgenic mice expressing a viral protein in oligodendrocytes leads to chronic central nervous system autoimmune disease. J. Exp. Med. 184, 2371-2384.

Fisher, E., Lee, J. C., Nakamura, K., and Rudick, R. A. (2008). Gray matter atrophy in multiple sclerosis: a longitudinal study. Ann. Neurol. 64, 255-265.

Fogdell-Hahn, A., Ligers, A., Gronning, M., Hillert, J., and Olerup, O. (2000). Multiple sclerosis: a modifying influence of HLA class I genes in an HLA class II associated autoimmune disease. Tissue Antigens 55, 140-148.

Ford, M. L., and Evavold, B. D. (2005). Specificity, magnitude, and kinetics of MOG-specific CD8+ T cell responses during experimental autoimmune encephalomyelitis. Eur. J. Immunol. 35, 76-85.

Friese, M. A., and Fugger, L. (2005). Autoreactive CD8+ T cells in multiple sclerosis: a new target for therapy? Brain 128, 1747-1763.

Friese, M. A., Jakobsen, K. B., Friis, L., Etzensperger, R., Craner, M. J., McMahon, R. M., Jensen, L. T., Huygelen, V., Jones, E. Y., Bell, J. I., and Fugger, L. (2008). Opposing effects of HLA class I molecules in tuning autoreactive $\mathrm{CD} 8(+) \mathrm{T}$ cells in multiple sclerosis. Nat. Med. 1227-1235.

Friese, M. A., Montalban, X., Willcox, N., Bell, J. I., Martin, R., and Fugger, L. (2006). The value of animal models for drug development in multiple sclerosis. Brain 129, 1940-1952.
Frohman, E. M., Racke, M. K., and Raine, C. S. (2006). Multiple sclerosis - the plaque and its pathogenesis. N. Engl. J. Med. 354, 942-955.

Galea, I., Bernardes-Silva, M., Forse, P. A., van Rooijen, N., Liblau, R. S., and Perry, V. H. (2007). An antigenspecific pathway for CD8 $\mathrm{T}$ cells across the blood-brain barrier. $J$. Exp. Med. 204, 2023-2030.

Gold, R., Linington, C., and Lassmann, H. (2006). Understanding pathogenesis and therapy of multiple sclerosis via animal models: 70 years of merits and culprits in experimental autoimmune encephalomyelitis research. Brain 129, 1953-1971.

Goverman, J. (2009). Autoimmune T cell responses in the central nervous system. Nat. Rev. Immunol. 9, 393-407.

Goverman, J., Woods, A., Larson, L., Weiner, L. P., Hood, L., and Zaller, D. M. (1993). Transgenic mice that express a myelin basic proteinspecific $\mathrm{T}$ cell receptor develop spontaneous autoimmunity. Cell 72, 551-560.

Goverman, J. M. (2011). Immune tolerance in multiple sclerosis. Immunol. Rev. 241, 228-240.

Greer, J. M., Sobel, R. A., Sette, A., Southwood, S., Lees, M. B., and Kuchroo, V. K. (1996). Immunogenic and encephalitogenic epitope clusters of myelin proteolipid protein. J. Immunol. 156, 371-379.

Hafler, D. A., Compston, A., Sawcer, S., Lander, E. S., Daly, M. J., De Jager, P. L., de Bakker, P. I., Gabriel, S. B., Mirel, D. B., Ivinson, A. J., PericakVance, M. A., Gregory, S. G., Rioux, J. D., McCauley, J. L., Haines, J. L., Barcellos, L. F., Cree, B., Oksenberg, J. R., and Hauser, S. L. (2007). Risk alleles for multiple sclerosis identified by a genomewide study. N. Engl. J. Med. 357, 851-862.

Hafler, D. A., Slavik, J. M., Anderson, D. E., O'Connor, K. C., De Jager, P., and Baecher-Allan, C. (2005). Multiple sclerosis. Immunol. Rev. 204, 208-231.

Hauser, S. L., Bhan, A. K., Gilles, F., Kemp, M., Kerr, C., and Weiner, H. L. (1986). Immunohistochemical analysis of the cellular infiltrate in multiple sclerosis lesions. Ann. Neurol. 19, 578-587.

Hoftberger, R., Aboul-Enein, F., Brueck, W., Lucchinetti, C., Rodriguez, M., Schmidbauer, M., Jellinger, K., and Lassmann, H. (2004). Expression of major histocompatibility complex class I molecules on the different cell types in multiple sclerosis lesions. Brain Pathol. 14, 43-50.
Huseby, E. S., Liggitt, D., Brabb, T., Schnabel, B., Ohlen, C., and Goverman, J. (2001a). A pathogenic role for myelin-specific CD8(+) T cells in a model for multiple sclerosis. J. Exp. Med. 194, 669-676.

Huseby, E. S., Sather, B., Huseby, P. G., and Goverman, J. (2001b). Agedependent $\mathrm{T}$ cell tolerance and autoimmunity to myelin basic protein. Immunity 14, 471-481.

Huseby, E. S., Ohlen, C., and Goverman, J. (1999). Cutting edge: myelin basic protein-specific cytotoxic $T$ cell tolerance is maintained in vivo by a single dominant epitope in $\mathrm{H}-2 \mathrm{k}$ mice. J. Immunol. 163, 1115-1118.

Ip, C. W., Kroner, A., Bendszus, M., Leder, C., Kobsar, I., Fischer, S., Wiendl, H., Nave, K. A., and Martini, R. (2006). Immune cells contribute to myelin degeneration and axonopathic changes in mice overexpressing proteolipid protein in oligodendrocytes. J. Neurosci. 26, 8206-8216.

Jacobsen, M., Cepok, S., Quak, E., Happel, M., Gaber, R., Ziegler, A., Schock, S., Oertel, W. H., Sommer, N., and Hemmer, B. (2002). Oligoclonal expansion of memory CD8+ T cells in cerebrospinal fluid from multiple sclerosis patients. Brain 125 , 538-550.

Jager, A., Dardalhon, V., Sobel, R. A., Bettelli, E., and Kuchroo, V. K. (2009). Th1, Th17, and Th9 effector cells induce experimental autoimmune encephalomyelitis with different pathological phenotypes. $J$. Immunol. 183, 7169-7177.

Ji, Q., Perchellet, A., and Goverman, J. M. (2010). Viral infection triggers central nervous system autoimmunity via activation of $\mathrm{CD} 8+\mathrm{T}$ cells expressing dual TCRs. Nat. Immunol. 11, 628-634.

Jiang, H., and Chess, L. (2006). Regulation of immune responses by $\mathrm{T}$ cells. N. Engl. J. Med. 354, 1166-1176.

Juedes, A. E., and Ruddle, N. H. (2001). Resident and infiltrating central nervous system APCs regulate the emergence and resolution of experimental autoimmune encephalomyelitis. J. Immunol. 166, 5168-5175.

Junker, A., Ivanidze, J., Malotka, J., Eiglmeier, I., Lassmann, H., Wekerle, H., Meinl, E., Hohlfeld, R., and Dornmair, K. (2007). Multiple sclerosis: T-cell receptor expression in distinct brain regions. Brain 130, 2789-2799.

Jurewicz, A., Biddison, W. E., and Antel, J. P. (1998). MHC class I-restricted lysis of human oligodendrocytes by myelin basic protein peptide-specific CD8 T lymphocytes. J. Immunol. 160, 3056-3059.
Kappler, J. W., Roehm, N., and Marrack, P. (1987). T cell tolerance by clonal elimination in the thymus. Cell 49, 273-280.

Kassmann, C. M., Lappe-Siefke, C., Baes, M., Brugger, B., Mildner, A., Werner, H. B., Natt, O., Michaelis, T., Prinz, M., Frahm, J., and Nave, K. A. (2007). Axonal loss and neuroinflammation caused by peroxisome-deficient oligodendrocytes. Nat. Genet. 39, 969-976.

Keegan, B. M., and Noseworthy, J. H. (2002). Multiple sclerosis. Annu. Rev. Med. 53, 285-302.

Killestein, J., Eikelenboom, M. J., Izeboud, T., Kalkers, N. F., Ader, H. J., Barkhof, F., Van Lier, R. A., Uitdehaag, B. M., and Polman, C. H. (2003). Cytokine producing $\mathrm{CD} 8+\mathrm{T}$ cells are correlated to MRI features of tissue destruction in MS. J. Neuroimmunol. 142, 141-148.

Kisielow, P., Bluthmann, H., Staerz, U. D., Steinmetz, M., and von Boehmer, H. (1988). Tolerance in T-cellreceptor transgenic mice involves deletion of nonmature $\mathrm{CD} 4+8+$ thymocytes. Nature 333, 742-746.

Krakowski, M., and Owens, T. (1996). Interferon-gamma confers resistance to experimental allergic encephalomyelitis. Eur. J. Immunol. 26, 1641-1646.

Krakowski, M. L., and Owens, T. (2000). Naive T lymphocytes traffic to inflamed central nervous system, but require antigen recognition for activation. Eur. J. Immunol. 30 1002-1009.

Kuchroo, V. K., Anderson, A. C., Waldner, H., Munder, M., Bettelli, E., and Nicholson, L. B. (2002). T cell response in experimental autoimmune encephalomyelitis (EAE): role of self and cross-reactive antigens in shaping, tuning, and regulating the autopathogenic $\mathrm{T}$ cell repertoire. Annu. Rev. Immunol. 20, 101-123.

Kyewski, B., and Klein, L. (2006). A central role for central tolerance. Annu. Rev. Immunol. 24, 571-606.

Langrish, C. L., Chen, Y., Blumenschein, W. M., Mattson, J., Basham, B., Sedgwick, J. D., McClanahan, T., Kastelein, R. A., and Cua, D. J. (2005). IL-23 drives a pathogenic T cell population that induces autoimmune inflammation. J. Exp. Med. 201, 233-240.

Lassmann, H., Bruck, W., and Lucchinetti, C. F. (2007). The immunopathology of multiple sclerosis: an overview. Brain Pathol. 17, 210-218.

Lees, J. R., Golumbek, P. T., Sim, J., Dorsey, D., and Russell, J. H. (2008). 
Regional CNS responses to IFNgamma determine lesion localization patterns during EAE pathogenesis. J. Exp. Med. 205, 2633-2642.

Lenercept. (1999). TNF neutralization in MS: results of a randomized, placebo-controlled multicenter study. The Lenercept Multiple Sclerosis Study Group and The University of British Columbia MS/MRI Analysis Group. Neurology 53, 457-465.

Limmer, A., Ohl, J., Kurts, C., Ljunggren, H. G., Reiss, Y., Groettrup, M., Momburg, F., Arnold, B., and Knolle, P. A. (2000). Efficient presentation of exogenous antigen by liver endothelial cells to $\mathrm{CD} 8+\mathrm{T}$ cells results in antigen-specific T-cell tolerance. Nat. Med. 6, 1348-1354.

Liu, G. Y., Fairchild, P. J., Smith, R. M., Prowle, J. R., Kioussis, D., and Wraith, D. C. (1995). Low avidity recognition of self-antigen by $\mathrm{T}$ cells permits escape from central tolerance. Immunity 3, 407-415.

Llewellyn-Smith, N., Lai, M., Miller, D. H., Rudge, P., Thompson, A. J., and Cuzner, M. L. (1997). Effects of anti-CD4 antibody treatment on lymphocyte subsets and stimulated tumor necrosis factor alpha production: a study of 29 multiple sclerosis patients entered into a clinical trial of cM-T412. Neurology 48, 810-816.

Lucchinetti, C., Bruck, W., Parisi, J., Scheithauer, B., Rodriguez, M., and Lassmann, H. (2000). Heterogeneity of multiple sclerosis lesions: implications for the pathogenesis of demyelination. Ann. Neurol. 47, 707-717.

Mars, L. T., Bauer, J., Gross, D. A., Bucciarelli, F., Firat, H., Hudrisier, D., Lemonnier, F., Kosmatopoulos, K., and Liblau, R. S. (2007). CD8 T cell responses to myelin oligodendrocyte glycoprotein-derived peptides in humanized HLA-A*0201transgenic mice. J. Immunol. 179, 5090-5098.

Massa, P. T., Ozato, K., and McFarlin, D. E. (1993). Cell type-specific regulation of major histocompatibility complex (MHC) class I gene expression in astrocytes, oligodendrocytes, and neurons. Glia 8, 201-207.

Mathis, D., and Benoist, C. (2004). Back to central tolerance. Immunity 20, 509-516.

McFarland, H. F., and Martin, R. (2007). Multiple sclerosis: a complicated picture of autoimmunity. Nat. Immunol. 8, 913-919.

Medana, I., Martinic, M. A., Wekerle, H., and Neumann, H. (2001). Transection of major histocompatibility complex class I-induced neurites by cytotoxic T lymphocytes. Am. J. Pathol. 159, 809-815.

Mildner, A., Djukic, M., Garbe, D., Wellmer, A., Kuziel, W. A., Mack, M., Nau, R., and Prinz, M. (2008). Ly-6G+CCR2- myeloid cells rather than Ly-6ChighCCR2+ monocytes are required for the control of bacterial infection in the central nervous system. J. Immunol. 181, 2713-2722.

Na, S. Y., Cao, Y., Toben, C., Nitschke, L., Stadelmann, C., Gold, R., Schimpl, A., and Hunig, T. (2008). Naive CD8 T-cells initiate spontaneous autoimmunity to a sequestered model antigen of the central nervous system. Brain 131, 2353-2365.

Neumann, H., Cavalie, A., Jenne, D. E., and Wekerle, H. (1995). Induction of MHC class I genes in neurons. Science 269, 549-552.

Neumann, H., Medana, I. M., Bauer, J., and Lassmann, H. (2002). Cytotoxic $\mathrm{T}$ lymphocytes in autoimmune and degenerative CNS diseases. Trends Neurosci. 25, 313-319.

Neumann, H., Schmidt, H., Cavalie, A., Jenne, D., and Wekerle, H. (1997). Major histocompatibility complex (MHC) class I gene expression in single neurons of the central nervous system: differential regulation by interferon (IFN)-gamma and tumor necrosis factor (TNF)-alpha. J. Exp. Med. 185, 305-316.

Niland, B., Banki, K., Biddison, W. E., and Perl, A. (2005). CD8+ T cellmediated HLA-A*0201-restricted cytotoxicity to transaldolase peptide 168-176 in patients with multiple sclerosis. J. Immunol. 175, 8365-8378.

Noseworthy, J. H., Lucchinetti, C., Rodriguez, M., and Weinshenker, B. G. (2000). Multiple sclerosis. N. Engl. J. Med. 343, 938-952.

O’Connor, R. A., Prendergast, C. T., Sabatos, C. A., Lau, C. W., Leech, M. D., Wraith, D. C., and Anderton, S. M. (2008). Cutting edge: Th1 cells facilitate the entry of Th17 cells to the central nervous system during experimental autoimmune encephalomyelitis. J. Immunol. 181, 3750-3754.

Okuda, Y., Sakoda, S., Bernard, C. C., Fujimura, H., Saeki, Y., Kishimoto, T., and Yanagihara, T. (1998). IL-6deficient mice are resistant to the induction of experimental autoimmune encephalomyelitis provoked by myelin oligodendrocyte glycoprotein. Int. Immunol. 10, 703-708.

Olsson, T., and Hillert, J. (2008). The genetics of multiple sclerosis and its experimental models. Curr. Opin. Neurol. 21, 255-260.
Ontaneda, D., Hyland, M., and Cohen, J. A. (2011). Multiple sclerosis: new insights in pathogenesis and novel therapeutics. Annu. Rev. Med. 63, 389-404.

Perchellet, A., Brabb, T., and Goverman, J. M. (2008). Crosspresentation by nonhematopoietic and direct presentation by hematopoietic cells induce central tolerance to myelin basic protein. Proc. Natl. Acad. Sci. U.S.A. 105, 14040-14045.

Perchellet, A., Stromnes, I., Pang, J. M., and Goverman, J. (2004). CD8+ T cells maintain tolerance to myelin basic protein by 'epitope theft.' Nat. Immunol. 5, 606-614.

Peterson, J. W., Bo, L., Mork, S., Chang, A., and Trapp, B. D. (2001). Transected neurites, apoptotic neurons, and reduced inflammation in cortical multiple sclerosis lesions. Ann. Neurol. 50, 389-400.

Prineas, J. W. (1979). Multiple sclerosis: presence of lymphatic capillaries and lymphoid tissue in the brain and spinal cord. Science 203, 1123-1125.

Raine, C. S., Mokhtarian, F., and McFarlin, D. E. (1984). Adoptively transferred chronic relapsing experimental autoimmune encephalomyelitis in the mouse. Neuropathologic analysis. Lab. Invest. 51, 534-546.

Ramagopalan, S. V., Knight, J. C., and Ebers, G. C. (2009). Multiple sclerosis and the major histocompatibility complex. Curr. Opin. Neurol. 22, 219-225.

Rock, K. L., and Shen, L. (2005). Cross-presentation: underlying mechanisms and role in immune surveillance. Immunol. Rev. 207, 166-183.

Sawcer, S., Hellenthal, G., Pirinen, M., Spencer, C. C., Patsopoulos, N. A., Moutsianas, L., Dilthey, A., Su, Z., Freeman, C., Hunt, S. E., Edkins, S., Gray, E., Booth, D. R., Potter, S. C., Goris, A., Band, G., Oturai, A. B., Strange, A., Saarela, J., Bellenguez, C., Fontaine, B., Gillman, M., Hemmer, B., Gwilliam, R., Zipp, F., Jayakumar, A., Martin, R., Leslie, S., Hawkins, S., Giannoulatou, E., D’Alfonso, S., Blackburn, H., Martinelli Boneschi, F., Liddle, J., Harbo, H. F., Perez, M. L., Spurkland, A., Waller, M. J., Mycko, M. P., Ricketts, M., Comabella, M., Hammond, N., Kockum, I., McCann, O. T., Ban, M., Whittaker, P., Kemppinen, A., Weston, P., Hawkins, C., Widaa, S., Zajicek, J., Dronov, S., Robertson, N., Bumpstead, S. J., Barcellos, L. F., Ravindrarajah, R.,
Abraham, R., Alfredsson, L., Ardlie, K., Aubin, C., Baker, A., Baker, K., Baranzini, S. E., Bergamaschi, L., Bergamaschi, R., Bernstein, A., Berthele, A., Boggild, M., Bradfield, J. P., Brassat, D., Broadley, S. A., Buck, D., Butzkueven, H., Capra, R., Carroll, W. M., Cavalla, P., Celius, E. G., Cepok, S., Chiavacci, R., ClergetDarpoux, F., Clysters, K., Comi, G., Cossburn, M., Cournu-Rebeix, I., Cox, M. B., Cozen, W., Cree, B. A., Cross, A. H., Cusi, D., Daly, M. J., Davis, E., de Bakker, P. I., Debouverie, M., D'Hooghe, M. B., Dixon, K., Dobosi, R., Dubois, B., Ellinghaus, D., Elovaara, I., Esposito, F., Fontenille, C., Foote, S., Franke, A., Galimberti, D., Ghezzi, A., Glessner, J., Gomez, R., Gout, O., Graham, C., Grant, S. F., Guerini, F. R., Hakonarson, H., Hall, P., Hamsten, A., Hartung, H. P., Heard, R. N., Heath, S., Hobart, J., Hoshi, M., Infante-Duarte, C., Ingram, G., Ingram, W., Islam, T., Jagodic, M., Kabesch, M., Kermode, A. G., Kilpatrick, T. J., Kim, C., Klopp, N., Koivisto, K., Larsson, M., Lathrop, M., Lechner-Scott, J. S., Leone, M. A., Leppä, V., Liljedahl, U., Bomfim, I. L., Lincoln, R. R., Link, J., Liu, J., Lorentzen, A. R., Lupoli, S., Macciardi, F., Mack, T., Marriott, M., Martinelli, V., Mason, D., McCauley, J. L., Mentch, F., Mero, I. L., Mihalova, T., Montalban, X., Mottershead, J., Myhr, K. M., Naldi, P., Ollier, W., Page, A., Palotie, A., Pelletier, J., Piccio, L., Pickersgill, T., Piehl, F., Pobywajlo, S., Quach, H. L., Ramsay, P. P., Reunanen, M., Reynolds, R., Rioux, J. D., Rodegher, M., Roesner, S., Rubio, J. P., Rückert, I. M., Salvetti, M., Salvi, E., Santaniello, A., Schaefer C. A., Schreiber, S., Schulze, C., Scott, R. J., Sellebjerg, F., Selmaj, K. W., Sexton, D., Shen, L., Simms-Acuna, B., Skidmore, S., Sleiman, P. M., Smestad, C., Sørensen, P. S., Søndergaard, H. B., Stankovich, J., Strange, R. C., Sulonen, A. M., Sundqvist, E., Syvänen, A. C., Taddeo, F., Taylor, B., Blackwell, J. M., Tienari, P., Bramon, E., Tourbah, A., Brown, M. A., Tronczynska, E., Casas, J. P., Tubridy, N., Corvin, A., Vickery, J., Jankowski, J., Villoslada, P., Markus, H. S., Wang, K., Mathew, C. G., Wason, J., Palmer, C. N., Wichmann, H. E., Plomin, R., Willoughby, E., Rautanen, A., Winkelmann, J., Wittig, M., Trembath, R. C., Yaouanq, J., Viswanathan, A. C., Zhang, H., Wood, N. W., Zuvich, R., Deloukas, P., Langford, C., Duncanson, A., Oksenberg, J. R., Pericak-Vance, M. A., Haines, J. L., Olsson, T., Hillert, 
J., Ivinson, A. J., De Jager, P. L., Peltonen, L., Stewart, G. J., Hafler, D. A., Hauser, S. L., McVean, G., Donnelly, P., and Compston, A. (2011). Genetic risk and a primary role for cell-mediated immune mechanisms in multiple sclerosis. Nature 476, 214-219.

Saxena, A., Bauer, J., Scheikl, T., Zappulla, J., Audebert, M., Desbois, S., Waisman, A., Lassmann, H., Liblau, R. S., and Mars, L. T. (2008). Cutting edge: multiple sclerosis-like lesions induced by effector CD8 T cells recognizing a sequestered antigen on oligodendrocytes. J. Immunol. 181, 1617-1621.

Sean Riminton, D., Korner, H., Strickland, D. H., Lemckert, F. A., Pollard, J. D., and Sedgwick, J. D. (1998). Challenging cytokine redundancy: inflammatory cell movement and clinical course of experimental autoimmune encephalomyelitis are normal in lymphotoxin-deficient, but not tumor necrosis factordeficient, mice. J. Exp. Med. 187, 1517-1528.

Seitz, S., Schneider, C. K., Malotka, J., Nong, X., Engel, A. G., Wekerle, H., Hohlfeld, R., and Dornmair, K. (2006). Reconstitution of paired $\mathrm{T}$ cell receptor alpha- and betachains from microdissected single cells of human inflammatory tissues. Proc. Natl. Acad. Sci. U.S.A. 103, 12057-12062.

Serafini, B., Rosicarelli, B., Magliozzi, R., Stigliano, E., Capello, E., Mancardi, G. L., and Aloisi, F. (2006). Dendritic cells in multiple sclerosis lesions: maturation stage, myelin uptake, and interaction with proliferating T cells. J. Neuropathol. Exp. Neurol. 65, 124-141.

Skulina, C., Schmidt, S., Dornmair, K., Babbe, H., Roers, A., Rajewsky, K., Wekerle, H., Hohlfeld, R., and Goebels, N. (2004). Multiple sclerosis: brain-infiltrating CD8+ T cells persist as clonal expansions in the cerebrospinal fluid and blood. Proc. Natl. Acad. Sci. U.S.A. 101, 2428-2433.

Sobel, R. A. (2000). Genetic and epigenetic influence on EAE phenotypes induced with different encephalitogenic peptides. J. Neuroimmunol. 108, 45-52.

Sospedra, M., and Martin, R. (2005). Immunology of multiple sclerosis. Annu. Rev. Immunol. 23, 683-747.

Steinman, L. (2001). Myelin-specific CD8 $\mathrm{T}$ cells in the pathogenesis of experimental allergic encephalitis and multiple sclerosis. J. Exp. Med. 194, F27-F30.

Steinman, L. (2009). A molecular trio in relapse and remission in multiple sclerosis. Nat. Rev. Immunol. 9, 440-447.

Steinman, L., and Zamvil, S. S. (2005). Virtues and pitfalls of EAE for the development of therapies for multiple sclerosis. Trends Immunol. 26, 565-571.

Stromnes, I. M., Cerretti, L. M., Liggitt, D., Harris, R. A., and Goverman, J. M. (2008). Differential regulation of central nervous system autoimmunity by $\mathrm{T}(\mathrm{H}) 1$ and $\mathrm{T}(\mathrm{H}) 17$ cells. Nat. Med. 14, 337-342.

Sun, D., Whitaker, J. N., Huang, Z., Liu, D., Coleclough, C., Wekerle, H., and Raine, C. S. (2001). Myelin antigenspecific CD8+ T cells are encephalitogenic and produce severe disease in C57BL/6 mice. J. Immunol. 166, 7579-7587.

Tennakoon, D. K., Mehta, R. S., Ortega, S. B., Bhoj, V., Racke, M. K., and Karandikar, N. J. (2006). Therapeutic induction of regulatory, cytotoxic CD8+ $\mathrm{T}$ cells in multiple sclerosis. J. Immunol. 176, 7119-7129.

Traugott, U., Reinherz, E. L., and Raine, C. S. (1983a). Multiple sclerosis. Distribution of T cells, $\mathrm{T}$ cell subsets and Ia-positive macrophages in lesions of different ages. J. Neuroimmunol. 4, 201-221.

Traugott, U., Reinherz, E. L., and Raine, C. S. (1983b). Multiple sclerosis: distribution of $\mathrm{T}$ cell subsets within active chronic lesions. Science 219, 308-310.

Tsuchida, T., Parker, K. C., Turner, R. V., McFarland, H. F., Coligan, J. E., and Biddison, W. E. (1994). Autoreactive $\mathrm{CD} 8+\mathrm{T}$-cell responses to human myelin protein-derived peptides. Proc. Natl. Acad. Sci. U.S.A. 91 10859-10863.

Tzartos, J. S., Friese, M. A., Craner, M. J., Palace, J., Newcombe, J. Esiri, M. M., and Fugger, L. (2008). Interleukin-17 production in central nervous system-infiltrating $\mathrm{T}$ cells and glial cells is associated with active disease in multiple sclerosis. Am. J. Pathol. 172, 146-155.

van Oosten, B. W., Lai, M., Hodgkinson, S., Barkhof, F., Miller, D. H. Moseley, I. F., Thompson, A. J., Rudge, P., McDougall, A., McLeod, J. G., Adèr, H. J., and Polman, C. H. (1997). Treatment of multiple sclerosis with the monoclonal antiCD4 antibody cM-T412: results of a randomized, double-blind, placebo-controlled, MR-monitored phase II trial. Neurology 49, 351-357.

Vanderlugt, C. L., and Miller, S. D. (2002). Epitope spreading in immune-mediated diseases: implications for immunotherapy. Nat. Rev. Immunol. 2, 85-95.

Waldor, M. K., Sriram, S., Hardy, R., Herzenberg, L. A., Lanier, L., Lim, M., and Steinman, L. (1985). Reversal of experimental allergic encephalomyelitis with monoclonal antibody to a $\mathrm{T}$ cell subset marker. Science 227, 415-417.

Wong, G. H., Bartlett, P. F., ClarkLewis, I., Battye, F., and Schrader, J. W. (1984a). Inducible expression of $\mathrm{H}-2$ and Ia antigens on brain cells. Nature 310 , 688-691.

Wong, G. H., Clark-Lewis, I., Harris, A. W., and Schrader, J. W. (1984b). Effect of cloned interferon-gamma on expression of $\mathrm{H}-2$ and Ia antigens on cell lines of hemopoietic, lymphoid, epithelial, fibroblastic and neuronal origin. Eur. J. Immunol. 14 52-56.

Wucherpfennig, K. W. (2001). Insights into autoimmunity gained from structural analysis of MHC-peptide complexes. Curr. Opin. Immunol. 13 , 650-656.
Wucherpfennig, K. W., Call, M. J., Deng, L., and Mariuzza, R. (2009). Structural alterations in peptideMHC recognition by self-reactive $\mathrm{T}$ cell receptors. Curr. Opin. Immunol. 21, 590-595.

Zamvil, S. S., and Steinman, L. (1990). The $\mathrm{T}$ lymphocyte in experimental allergic encephalomyelitis. Annu. Rev. Immunol. 8, 579-621.

Zang, Y. C., Li, S., Rivera, V. M., Hong, J., Robinson, R. R., Breitbach, W. T., Killian, J., and Zhang, J. Z. (2004). Increased $\mathrm{CD} 8+$ cytotoxic $\mathrm{T}$ cell responses to myelin basic protein in multiple sclerosis. J. Immunol. 172, 5120-5127.

Zhang, J., Medaer, R., Stinissen, P., Hafler, D., and Raus, J. (1993). MHC-restricted depletion of human myelin basic protein-reactive T cells by $\mathrm{T}$ cell vaccination. Science 261 , 1451-1454.

Zheng, Y., and Rudensky, A. Y. (2007). Foxp3 in control of the regulatory $\mathrm{T}$ cell lineage. Nat. Immunol. 8, 457-462.

Conflict of Interest Statement: The authors declare that the research was conducted in the absence of any commercial or financial relationships that could be construed as a potential conflict of interest.

Received: 11 January 2012; paperpending published: 04 February 2012; accepted: 15 March 2012; published online: 29 March 2012.

Citation: Huseby ES, Huseby PG, Shah S, Smith $R$ and Stadinski BD (2012) Pathogenic CD8 T cells in multiple sclerosis and its experimental models. Front. Immun. 3:64. doi: 10.3389/fimmu.2012.00064

This article was submitted to Frontiers in Inflammation, a specialty of Frontiers in Immunology.

Copyright (C) 2012 Huseby, Huseby, Shah, Smith and Stadinski. This is an openaccess article distributed under the terms of the Creative Commons Attribution Non Commercial License, which permits non-commercial use, distribution, and reproduction in other forums, provided the original authors and source are credited. 